EDMUND JARMUSIK (Grodno)

\title{
BIALORUSKA HISTORIOGRAFIA Z LAT 1991-2004. NOTY BIBLIOGRAFICZNE. Część III 1
}

\section{1 год}

ЮХхо Іосіф. Крыніцы беларуска-літоўскага права. - Мінск, «Белгарусь», 1991. - 238 с.

Книга знакомит с богатым наследием ВKJI эюохи феодализма, которое воплошено в правовых актах этого государства. Их основы составило белорусское «звычаёвае і пісанае права», которое происходит из древних времен и закреплено в грамотах и Статутах. Автор исходит из того, что «намятники права являются наиболее точными и надежными источниками знаний об экономике, классовой и сословной структуре обшества, государственном строе, судебных и государственных учреждениях, общественных отнопениях. В них получили отражение философские, обшественно-политические и правовые идеи народа, его культура и быт». Анализируются источники права (грамоты, статуты, привилеи, судебники). Болыше всего внимания уделено Статуту 1588 года. Исследуются особенности государственного и военного права, судебного устройства и процессуального права, гражданского, семейного, уголовного права. Отдельный раздел посвяшен правовому анализу Унии ВKJI и ІІолыпи 1569 года.

1 Część I i II ukazały się w tomach XIII (2003) i XIV (2004) „Studiów Podlaskich”. 
1994 год

Сорокин И. Н. Эксперимент человек и земля / под редакцией доктора исторических наук Л. М. Лыча. - Минск, Навука і тэхніка, 1994. -96 c.

Автор поднимает ряд проблем, связанных с коллективизацией в Беларуси, абсолютизацией государственной собственности, первой попыткой разрушения сталинизма, пробует осмыслить их с позиций сегодняшнего дня. В книге ставится цельь - переосмыслить принадлежавпие проплому попытки решения аграрно-крестьянской проблемы в Беларуси. Имеюшиеся в отечественной историографии работы в основу процесса зарождения и развития социалистического производства в сельском хозяйстве ставят экспроприацию земледельцев (раскулачивание). Отсюда следовал вывод: преврашение частной собственности, основанной на личном труде или на использовании чужого труда, в социалистическую общественную приведет к расцвсту социалистических производственных отнопений и достижению наивыспей производительности труда. Автор показывает предпосылки, условия, ход проведения массовой коллективизации в деревне, внедрение новых форм собственности (колхозы, совхозы). Приводятся конкретные примеры, показываюшие разрупительное влияние принудительного сгона крестьян в колхозы, раскулачивания. Освеццаются некоторые особенности политики болышевистской партии в деревне, созданной ею карательной системы против крестьянства. Прослеживается и такой наболевший вопрос, как демократия в колхозах. Анализируются причины, приведние к кризисному состоянию) в агропромыпленном комплексе страны.

\section{5 год}

Швед В. В. Падзеі і постаці Гродзенскай даўніны. - Гродна, 1995. - $176 \mathrm{c}$.

События, описываемые в книге, основаны на архивных источниках и охватывают период с конца XVII до начала XX века. Территориально охватывают нынешнюю Гродненшину, Брестчину и Белосточчину. Очерковый характер книги позволил автору отобрать наиболее интересные, на его взгляд, события и их героев: второй раздел Речи Посполитой, 
деятельность новогрудских масонов, вненнеторговые связи Гроднен(кой губернии, восстание 1863 года в Слонимском уезде и другие. ГІриводятся интересные факты из жизни известных или малоизвестных лиц: художников Юлиана Карчевского и Яна Трояновского, поэта Адама Мицкевича, повстанца Людвика Нарбута, историка Евстафия Орловского.

\section{6 год}

Цітоў В. С. Этнаграфічная спадчына. Беларусь. Краіна і людзі. Вучэбна-метадычны дапаможнік. - Мінск, Беларусь, 1996. -208 c.

Книга дает основы этнографических знаний о белорусском народе (этносе) и его древней культуре. В первой тас:ти дается характеристика основных этнографических понятий, кратко прослеживается этногенез и этнические процессы в Белоруссии, особенности геополитического положения территории республики, связей белорусов с соседями (русскими, украинцами, поляками, литовцами) и другими (евреи, цыгане, татары). Автор выделяет и кратко описывает историко-этнографические регионы: ІІдвинье (Поозерье), Поднепровье, Центральная Беларусь, ІІонеманье, Восточное Полесье и Западное Полесье. Описание каждого из регионов включает пеографическче положение, особенности исторического развития. природа края, занятия населения, быт, традиционная культура. Рассматривается историко-этнографическое развитие смежных регионов: Вильно, Брянцины, Латгалии, а также белорусской эмиграции. Кратко характеризуются некоторые этнические группы, проживаюшие в Беларуси: русские, поляки, украинцы, литовцы, евреи, татары, цыгане.

\section{8 год}

Швед В. В. Беларускія старонкі гісторы дзекабрыстаў. Мінск, 1998. - 132 с.

В основе работы - исследование малоизвестных или неизвестных страниц жизни и деятельности русских революционеров-декабристов в начале XIX века на территории нынепней Беларуси. Среди них 
- И. И. Горбачевский, Н. И. ІІушџн, II. II. ІІасека, В. В. Горский и другие. В книге освеццется деятельность декабристской организапии «Военные друзья» в Гродненской губернии, ее связь с Южными и Северными декабристскими обществами России, участие будуших повстанцев в заграничных походах русской армии в 1813-1815 гг.

ІІоднимается проблема роли и места белюрусского края в тактике декабристов (в программных документах, бобруйском заговоре 1823 года, попытке C. II. Трусова поднять военное восстание в Бобруйской крепо:ти в 1926 г.). Заключительная глава освешает леятельнность военно-судейской комиссии в Могилеве (через нее прошли 30 декабристов) и приговоры по делу декабристских тайных организаций. Книга написана на болыном архивном материале. Использованы исследования белорусских, советских, российских исследователей.

\section{0 год}

Грыцкевіч В. П. Гісторыя і міфы. - Мінск, 2000. - 205 с.

Исследуемая в книге 'гематика отличается разнообразием, актуальностью и новаторством. Автор пытается критически осмыслить новейпую историю, взглянуть не с официальных позиций на Беларусь и белюрусов.

В первом разделе «ІІредостережение» анализируются глубинные причины многих исторических событий, называются причины, которые вынуждали историков отходить от правды, создавать и распространять мифы и легенды, становясь при этом заложниками той или иной идеи. Здесь же рассматриваются истоки и наследие тоталитаризма, его влияние на человеческие судьбы, моральное состояние общества. В разделе «История в меняюшемся мире» на ярких примерах автор рассматривает роль исторических знаний в жизни каждого человека, особенно молодежи. В последнем разделе «Мифы и история» В. Грицкевич исследует происхождение, содержание некоторых мифов и легенд, которые более ста тридцати последних лет существовали в белорусской истории. В книге сообщается о типичных политических мифах, как общенародная собственность в советские времена, об отсутствии класса эксплуататоров в социалистическом обществе, о правильности марксистско-ленинской теории, силе, правдивости коммунистической партии, классовой борьбе и другие. 
2001 год

Кузьменко В. И. Интеллигенция Беларуси в период немецко-фашистской оккупации (1941-1944 гг.) - Минск, 2001. -200 c.

Монография является непосредственным продолжением предыдушей - «Советская интеллигенция в патриотическом движении Беларуси. 1941-1944». Мн., 1991. Она более полно освещает участие интеллигенции в подпольной борьбе на основе изучения политики оккупантов в отношении к интеллектуальной элите, исследования проблемы «коллаборация и интеллигенция». В книге используются документы, ранее не доступные историками, значительное количество статистического материала.

Автор более основательно освешает тактическюе маневрирование оккупационных властей в социальной и культурной областях, в отношении к кадрам местных специалистов, стремление гитлеровцев использовать их в условиях военной обстановки, которая изменялась не в пользу Германии. Оккупанты и их пособники умело использовали в своей парадигме политические ошибки советского руководства в хозяйственной, религиозной и других сферах.

В книге более широко использованы материалы советского подполья в населенных пунктах республики. Показано участие интеллигенции в деятельности подпольных организаций, партизанских формирований, руководящих структур антифашистской борьбы.

C новых позиций рассматриваются в монографии участие представителей интеллигенции в пропагандистской, массово-просветительской работе партизан и подполыциков. При этом автор отмечает, 'то большинство советской интеллигенции находилюсь под влиянием сталинизма.

Автор акцентирует внимание и на проблеме сотрудничества части белорусской интеллигенции с оккупантами, исследование причин этого явления. Исследователь показал бессмысленность коллаборантских устремлений, крах иллюзий достигнуть независимость Беларуси, опираясь на нацизм. поднять культуру народа при помощи гитлеровцев. 


\section{2 год}

Новікаў С. Я. Эканамічная палітыка нацысцкай Германіi ў Беларусі 1941-1944 гг. (агляд крыніц і германскай гісторыяграфіi 1990-х гадой). - Мінск, 2002. - 219 с.

В монографии анализируются исключительно немецкоязычные источники и новейпгая германская историография. Автор исходит из необходимости использования нетрадиционных подходов изучения оригинальных и уже известных немецкоязычных первопсточников, без купюр и сокрацений. IIо мнению автора, важно использовать новые научные разработки современной германской историографии для проведения всестороннего анализа экономической политики нацистской Германии на оккупированной территории Беларуси.

В монографии использовано много малоизвестных документов из фондов Национального архива Республики Беларусь, Федерального архива Германии (Фрайбург), Федерального архива Германии (Берлин), Российского государственного военного архива (Москва). Среди несомненно интересных и оригинальных первоисточников - малоизвестные документы, как «зеленая папка». «коричневая папка» и ряд других.

Тшательное изучение источников и германской историографии привели автора к мысли, что «перед отечественной исторической наукой стоит чрезвычайно сложная задача - либо оставаться в рамках разработанных ранее методологических подходов, либо знать правдивую историю оккупации Беларуси в годы второй мировой войны».

В монографии рассматриваются основные концепции экономической политики нацистов, структура военного руковопства на оккупированной территории Белоруссии, политика и практика военной и гражданской администрации в области хозяйства и продовольствия, германской политики деиндустриализации, использования рабочей силы и другие.

В конце монографии дается приложение из 15 немецкоязычных документов, переведенных автором на белорусский язык.

\section{3 год}

Пичета В. И. История белорусского народа. - Минск, Издательский центр БГУ, 2003. - 184 с.

Издание приурочено к 125-летию со дня рождения замечательного ученого-историка, одного из создателей и первого ректора Белорусского 
государственного университета (БГУ), одного из организаторов Института белорусской культуры (Инбелкульта) и Академии наук БССР, Института славяноведения и кафедры истории южных и западных славян Московского госуниверситета академика Владимира Ивановича Пичеты (1878-1947). В книгу вошли труды «История белорусского народа» и «История Литовского государства до Люблинской унии», не переиздававшиеся со дня первого выхода в свет. Они посвяшены истории Беларуси и соответствуют главному кругу проблем, которые интересовали ученого.

В первой части книги освещены проблемы формирования территории и населения Беларуси, история белорусского племени до конца XIII века, образование Јитовско-Русского государства и положение Белоруссии в его составе, православие и католицизм на белорусских землях. Характеризуются отдельные социальные слои населения (крестьянство, шляхта), этнические группы (евреи, политика Русского государства в конце XVIII - начале XX века и другие.

Вторая часть посвяцена проблемам возникновения Литовского государства, его политической, социально-экономической истории, внепней политики. Освещаются причины и характер внутренних противоречий в BKJI, общественный и политичес:кий строй, национально-политическая борьба.

Токць С. М. Беларуская вёска на мяжы эпох: Змены этнічнай самасвядомасці сялянства ва ўмовах распаду традыцыйнага аграрнага грамадства (па матэрыялах Гарадзеншчыны XIX першай трэці XX ст.). манаграфія. - Гродна, ГрДУ імя Янкі Купалы, 2003. - 191 с.

В монографии рассматриваются изменения этнического самосознания белорусского крестьянства на историческом материале Гродненшины. Исследование носит исторический характер, хотя в нем использованы этнологические и социологические модели. Описываемая в работе историческая реальность носит динамический характер и отражает переплетение взаимосвязанных социальных и культурных процессов.

Јокализация исследования Гродненским регионом позволиила автору основательно, детально раскрыть процессы изменений в этническом самосознании местнопо крестьянства. Рассматриваются теоретические аспекты проблемы, очерчены подходы к определению таких понятий, как этничность, этническая группа, нация, этническое и национальное 
самосознание. На историческом материале Гродненской губернии рассматриваются этнические процессы в местной крестьянской среде во времена Российской империи. Анализируются ассимиляторские влияния польской и российской национальных культур, специфика этнических процессов в католической и православной среде белорусской деревни. Акцентируется внимание на процессах изменения самосознания крестьянства в условиях крушения замкнутости крестьянской обшности в период первой мировой войны и российских революций.

В монографии использованы труды белорусских, российских, польских историков. Источниковой базой послужили материалы Национального исторического архива в Гродно и Г'осударственного исторического архива Гродненской сбласти, а также материалы этнографических исследований, статистические данные, периодическая печать, мемуары и дневники соотечественников.

Черепица В. Н. ... Не потерять связуюоцую нить. История Гродненцины XIX-XX столетия в событиях и лицах (исследования, документы, комментарии). - Гродно, 2003. - 420 с., иллюстрации.

Предметом и смыслом данной работы являются как известные исторические деятели (Н. М. Карамзин, П. А. Столыпин, И. П. Трутнев), так и менее известные (Л. Рейснер, А. ЈI. Чижевский), или вовсе неизвестные (В. В. Богданович, С. П. Белайц) и др. Автор возвраццает их из небытия, показывает связь с Гродненцциной, говорит о их величине и вкладе в историко-культурное развитие Гродненского края. Не все герои очерков трактовались прежде однозначно, равно как и оценка их творчества и деятельности были разными. В книге сделана попытка «глубоко погружаться в мотивы их постунков и мыпления, делать их своими». В книге публикуется много выявленных в последнее время профессором В. Н. Черепицей архивных и других документов по истории Гродненшины. Болынинство впервые вводится в научный оборот. Книга иллюстрирована фотографиями, ксерокопиями некоторых документов.

\section{4 год}

Анішчанка Яўген. Камісары Касцюшкі. 3бор твораў у 6-ці тамах. Том 1. Дакументы паўстання 1794 г. у Літойстай правінцыі. - Мінск, Выд. Хурсік, 2004. - 364 с. 
Собрание произведений в 6 томах будет включать в себя уникальные, ранее не известные документы из архивов Беларуси и зарубежья.

В первых трех томах будут представлены документы, относящиеся к периоду восстания под руководством Тадеуша Костюпко. В следуюцих - документы о разделах Речи Посполитой, а также инкорпорации Беларуси в состав России.

В первом томе содержатся документы о восстании 1794 года в BKJI из архива Польской академии наук в Курнике. Ценность их в том, тто они тохно отражают деятельность порядковых комиссий восстания (особенно Гродненской) за весь период их существования. В частности, в сборнике почти полностью опубликованы диаруши о деятельности Гродненской порядковой комиссии весь период ее суцествования. Уникальность сборника в том, тто он в деталях позволяет представить весь облик исполнительной власти на местах.

Территориально они охватывают Виленское воеводство и 9 уездов (поветов): Ошмянский, Завилейский, Эйшинский, Јидский, Вилькомирский, Браславский, Трокский, Меречский, Гродненский. Документы даны в авторском переводе на белорусский язык.

Атлас гісторы Беларусі ад старажытнасці да нашых дзён (дадатак да 6-томнай «Энцыклапедыі гісторыі Беларусі»). Мінск: «Беларуская энцыклапедыя», 2004. - 160 с.

В издании включены карты, планы, схемы, а также другой иллюстрационный материал. Он представляет собой историю Беларуси, отраженную в картах, от глубокой древности до наших дней. В атласе помешены картографические материалы, в том числе о важнейпих археологических культурах, которые существовали на территории Беларуси со времен палеолита, о первых государственных образованиях на ее территории, о вхождении земель Беларуси в состав BKJI, Речи Іосполитой, Российской империи. Отдельные карты посвящены войнам 16-19 в., которые проходили на территории Беларуси, в том числе Северной войны 1700-1721 гг., войны 1812 г., первой мировой войне. Блок карт посвяцен событиям Великой Отечественной войны. Ряд материалов отражает историю БССР и историю независимой Республики Беларусь.

Беларусь у Вялікай Айчыннай вайне. Дзень за днём. Ілюстраваная храналогія. - Мінск: «Беларусь», 2004. - 232 с. 
Книга посвяцена 60-летию освобождения Беларуси от гитлеровцев. В книге день за днем последовательно отражаются три года оккупации: наиболее значимое и известное, что происходило в то время в республике, что создавало обцую документальную картину тогдашних событий. Показаны трагические и героические страницы истории белорусского народа. Книга иллюстрирована многочисленными документальными фотографиями, картами военных действий, рисунками.

Болбас В. С. Этыка - педагагічная думка Беларусі (са старажытнасці да XVIII ст.). - Мінск: «Беларуская навука», 2004. -260 c.

В монографии анализируются источники, факторы и условия развития этико-педагогической мысли на белорусских землях с древних времен до XVIII в. Показана сушность и структура морально-воспитательного процесса в представлении деятелей отечественной педагогической и обцественной мысли. Широко представлены идеи отечественных мыслителей: К. Туровского, К. Смолятича, Е. Полоцкой, Ф. Скорины, М. Гусовского, С. Будного, Я. Намысловского, С. Рысинского, К. Лышинского, С. Полоцкого, И. Капиевича, А. Цовгирда, Ф. Бохвица и других.

Вашкевіч Юры. Беларуска-польскія культурныя сувязі ў 1945-1991 гадах. Мінск: ТЭСЕЙ, 2004. - 184 с.

Книга охватывает период существования Беларуси в составе СССР после второй мировой войны. В ней дана характеристика этапа белорусско-польских культурных отнопений на фоне обцественно-политической ситуации в обеих странах. Анализируются отдельные направления этого сотрудничества, восприятие белорусской культуры в Полыпе, состояние исследования польской белорусстики и историографии. Рассмотрена культурная деятельность польских белорусов, а также связанная с Беларусью польская мемуаристика этого периода.

Гісторыя кінамастацтва Беларусі. У 4 тамах. Т.3 Тэлевізійнае кіно (1956-2002 гг.) / В. Ф. Нячай, В. А. Мядзведзева, Н. А. Агафонава; нав. рэд. В. Ф. Нячай. - Мінск: Беларуская навука, 2004. - 374 с. 
Книга является третьей частью четырехтомного труда и посвяцена белорусскому художественному и документальному телевизионному кино, творчеству его ведущих мастеров. Значительное внимание уделено рассмотрению телекино в контексте художественной культуры и литературы Беларуси. Рассказывается об истории возникновения и развития белорусского художественного и документального кино, об отражении в нем менталитета белорусов, его связи с духовными процессами в жизни народа, с отражением в кино образов природы, тем истории и культуры. В проблемно-тематических главах рассматриваются такие важные аспекты, как телеэкран и духовный опыт войны, возрождение исторической памяти в телефильмах, образы художников на телеэкране, детское кино Беларуси, эволюция жанров и стилей в телевизионном художественном и документальном кино.

Гродненская губерния в законодательных актах Российской империи (1801-1913) / Сост. Т. Ю. Афанасьева и др.; под ред. В. Н. Черепицы. - ГОУПП «Слонимская типография», 2004. 360 c.

В книге содержится 106 документов, размеценных в хронологическом порядке, 66 репродукций рисунков. Сборник посвящен истории Гродненской губернии. В нем собраны законодательные акты, содержапиеся в трех изданиях «ІІолного собрания законов Российской империи (1830-1913)». В настояшем уникальном издании впервые комплексно представлены документы, раскрываюцие главные вехи губернского периодов ІІринеманья. Многие из публикуемых документов давно превратились в библиографическую редкость.

Сборник охватывает широкий спектр законодательных актов (царских указов, повелений, Законов Государственной думы, Мнений Государственного Совета, выписок, правил, положений и др.) по различным вогросам, касаюгимся административно-территориального устройства и аппарата правления, поземельного устройства крестьян, национально-сословных отношений, конфискапии имушества участников восстаний и др.

Гурэвіч Ф. М. Летапісны Новогородок (Старажытнарускі Наваградак). - Санкт-Пецярбург - Наваградак, 2003. - 324 с.

Книга посвяцена результатам 25-летнего изучения древнего Новогородка - дединца и окольного города. Детальному анализу подверг- 
нуты письменные источники, их интерпретация в работах историков. Представлены концепции о происхождении древней столицы BКJ, исследуется ранний период еє истории. Значительное место уделяется во просам топографии - оборонительным сооружениям, планировке и домостроительству, развитию ремесла, оружейного дела, сельского хозяйства и промыслов, торговли, внешних связей. Акцентируется внимание на развитии духовной культуры и социальном облике Новогрудка.

Книга иллюстрирована оригинальными рисунками, фотографиями, снабжена прилюжениями.

Кадровый потенциал науки Республики Беларусь. Монография. - Минск: УП «Технопринт», 2004. - 259 с.

В монографии представлены основные тенденции развития кадрового потенциала белорусской науки, его отраслевой, квалиффикационной и возрастной структуры. Проанализированы состояние и пути совершенствования республиканской системы подготовки и повыпения квалификации научных кадров. Рассмотрены проблемы государственного регулирования научных и научно-педагогических кадров. Особое внимание уделено проблеме научной молодежи, совершенствованию социально-экономического механизма привлечения и закрепления молодых специалиистов в науке.

Лабачэўская Вольга. Повязь часоў - беларускі ручнік. - Мінск: «Беларусь», 2002. - 232 с.

Монография посвяшена белорусскому ручнику - символу белорусской национальной культуры. В книге опубликовано 200 образцов белорусских ругіников, которые были созданы на протяжении примерно одного века - с 1870-x по 1980-е гг. Все они сгруппированы по историко-этнографическим регионам Беларуси. В отдельный раздел выделены выпитые ручники конца XIX - начала XX в. Исследуются особенности изготовления ручников, их ритуальные, обрядовые, декоративные функции, характер декора и его композиция.

Макеева И. Е. Отцы и дети из 41-го. Страницы истории. 2-е издание, дополненное. - «ГОУПП и Гродненская типография», 2004. - 360 с.

Книга составлена известным гродненским краеведом И. Е. Макеевой. Более 60 лет она занимается сбором материалов о первых боях на 
Гродненшине и Белосточчине, ведет болыную переписку с участниками этих событий. Собранный еюо уникальный «живой» материал через восприятие очутившихся в пламени войны людей показывает весь трагизм и героизм тех дней, рассказывает о судьбах простых людей, вынесших на своих плечах невзгоды военного лихолетья.

Памяць. Ашмянскі раён. Гісторыка-дакументальная хроніка. - Мінск, БелТА, 2003. - 688 с.

Памяць. Слонімскі раён. Гісторыка-дакументальная хроніка. Мінск, БелТА, 2004. - 752 с.

Памяць Ліда. Лідскі раён. Гісторыка-дакументальная хроніка. - Мінск, «Беларусь», 2004. - 566 с.

В книгах рассказывается о событиях, связанных с историей этих регионов в контексте тех исторических процессов, которые в целом проходили на земле Беларуси. Авторы стремились показать историческое прошлое таким, каким оно было.

В хронике Памяти отражается не только собятия прошлых веков, но и новой истории, связанной с революциями, оккупациями, мирным развитием. Особенно болыпое внимание уделено трагическим и героическим собятиям Великой Отечественной войны. Увековечены поименно воины, партизаны, подполыцики, мирные жители, что погибли от рук гитлеровцев. Приводятся сведения о жертвах политических репрессий в советское время. Много внимания уделено истории культурного развития. Прославляются знаменитые земляки, которые внесли весомый вклад в развитие народного хозяйства, науки, культуры, искусства. Описано богатое материальное и духовное наследие населенных пунктов.

При подготовке книг использовались документы белорусских архивов, музеев, воспоминания участников событий, материалы энциклопедических и других изданий.

Падокшын С. А. Этычная думка ӱ культуры Беларусі XVI-XVII ст. -- Мінск: Беларуская навука, 2004. -- 151 с.

В книге впервые представлена общая целостная картина морального самосознания белорусского феодального общества XVI-XVII вв. анализируется корпоративная этика белорусских горожан, этическая мысль 
эпохи отечественного Возрождения и. Реформации, этические взгляды некоторых преподавателей православных братских пाкол, этика в католических учебных заведениях.

Небезынтересны взгляды автора на философско-этическую концепцию Андрея Волана, несвижский «Катехизис» 1562 года, реформаторские интенции в этике Франциска Скорины и другие.

Свиб А. Ф. Государственно-правовой статус Беларуси в составе России в пореформенный период (1861-1900). Минск, «Белорусский Институт правоведения», 2004. - 121 с.

В монографии рассматриваются вопросы отношений Беларуси и России, проблемы национально-освободительных движений на территории Северо-западного края Российской империи, борьбы классового и национального, религиозного, политического и идеологического характера. Научная новизна работы прежде всего в том, что по этому периоду практически нет историко-юридических исследований. Автор характеризует военно-бюрократический аппарат царской России на территории белорусских губерний; основные направления его политики; особенности проведения реформ в Беларуси во 2-й половине XIX века; правовые и политические идеи К. Калиновского, прогрессивных литераторов Ф. Богупевича и А. Гуриновича, в программных документах политических движений в Беларуси.

Стэфан Баторый у гістарычнай памяці народаў Усходняй Еўропы. Матэтыялы міжнароднага круглага стала. Гродна, 26 верасня 2003 г. - Гродна, 2004. - 328 с.

Материалы этой книги дают возможность узнать о разработках белорусских и польских ученых в области исследования Речи Посполитой и ВКЛ времен правления выдаюшегося государственного деятеля второй половины XVI века короля Стефана Батория, который оставил значительный след в исторических событиях Восточной Европы. В книге представлены тексты докладов, прочитанных в Гродно 26 сентября 2003 года во время «круглого стола» «Стефан Баторий в исторической памяти народов Восточной Европы». В числе докладов «Величие правителя, соединенное с трагедией человека» С. Морозовой, «Религиозная ситуация в Речи ІІосполитой во время правления С. Батория» Г. Васюка, «Эпоха С. Батория в трудах гродненского краеведа П. О. Бобровского» Е. Меленко и др. 
Вторая часть издания содержит монографию А. Литвинского и Д. Карева «Западноруссизм в российской историографии второй половины XIX - начала XX веков».

Цвірка Кастусь. Край легенд. Гісторыя Беларусі паводле паданняў і легендаў. - Мінск: «Беларускі кнігазбор», 2004. $400 \mathrm{c}$.

Книга представляет связанные между собой исторические рассказы, написанные на основе легенд и преданий из самых разнообразных источников. Среди них - о полоцком князе Брячиславе, основании Менска, татарах на Беларуси, возникновении ВКЛ, литовских князьях, Ливонской войне, Люблинской унии и другие. В книге прослеживается история Беларуси с древних времен до XVI века.

Язэп Лёсік. 1921-1930. Збор твораў. / Укладальнік, прадмова і каментарый А. Жынкіна. - Мінск, НАРБ: Выд. Логвінаў, 2003. - 369 c.

В книге помешены все выявленные публицистические и научные произведения Я. Лёсика, одного из видных белорусских национальных деятелей начала XX века. Произведения даны в хронологическом порядке. Сохранилось тогдапнее правописание. Книга содержит и именной показатель. Предусмотрен ее электронный вариант (azh@inbox.ru). 